\title{
ECONOMIC THRESHOLD AND ECONOMIC INJURY LEVELS FOR RICE STEM BORER, USING SIMULATED WHITE HEADS IN RICE
}

\author{
AMANY S. EL-HEFNY \\ Field Crop Pests Research Department, Plant Protection Research Institute, ARC, \\ Dokki, Giza, Egypt
}

(Manuscript received 31 March 2016)

\begin{abstract}
$\mathrm{R}$ ice (Oryza sativa L.) ranks second to wheat in area and production on the global level. Unfortunately, it is attacked by several insect pests. The rice stem borer, Chilo agamemnon Bles. is the most important in Egypt. The current investigation was carried out at the Experimental Farm of Sakha Agricultural Station, Kafr EL-Sheikh Governorate in 2013 and 2014 rice seasons using two cultivars, Giza 178 (high tillering capacity) and Egyptian Jasmine (medium tillering capacity) to establish the correlation between borer infestation as white heads and rice yield losses to determine the economic threshold and injury levels of C.agamemnon infestation in rice fields. Due to the great difficulty to use the technique of artificial infestation by the rice stem borer, the simulated technique (panicle removal) was applied to induce different levels of simulated white heads. The panicles were removed by hand to get gradual levels of stimulated white heads; $0,2,4,6,8,10,12,14$ and 16\%. Yield components (panicle weight, 1000-grain weight and filled grain \%) increased at the higher levels of panicle removal. This could be interpreted in the light of phenomenon compensation. This phenomenon suggests that the nutrients going to removed panicles are translocated to the adjacent ones. Consequently, the panicles adjacent to the removed ones become healthier than normal, and compensate, to a certain extent, the removed ones. The final grain yield was negatively affected, in the current study, by high levels of panicle removal. In Giza 178 rice cultivar (high tillering), the grain yields were 2315, 2295 and 2311, match to $1815,1755 \& 1781 \mathrm{~g} / 2 \mathrm{~m}^{2}$ at $0,2 \& 4 \%$ panicle removal, respectively. However, in both cultivars, the lowest grain yields were at 12, 14 1nd $16 \%$ simulated white head (panicle removal). Considering the cost of chemical control against the rice stem borer, and obtained grain yield at different levels of simulated white heads, economic threshold and economic injury levels were estimated. In Giza 178, the economic threshold was determined as 10 and economic injury as $12 \%$ white heads (panicle removal), while the economic threshold level of Egyptian Jasmine cultivar was determined as $8 \%$ white heads, and economic injury as $10 \%$ white heads. These results are important to the decision makers and rice growers to avoid using insecticides before the rice stem borer infestation reaches the economic threshold. On the other hand, economic threshold level should be assessed under several circumstances, e.g. location, cultivar, cultural practices, prices of insecticides and prices of rice.
\end{abstract}




\section{INTRODUCTION}

Rice (Oryza sativa L.) ranks second to wheat in the area and production on the global level (Anonymous, 2000). It is the staple food for about half of the world population, and it generates employment and income for rural people (Suhail et al., 2008). Because of the progressive increase of the world population, it has been necessary to increase rice production in the next decades.

Unfortunately, insect pests are among various constraints for sufficient rice production. The hot weather and high humidity are suitable circumstances for insect proliferation (Pathak et al., 2002). Many insect pest species appear sporadically but do not cause economic losses, however, a few species cause a significant damage, and are extremely important (Sherif et al. 1999). The stem borers, belonging to order Lepidoptera, are widely distributed as economic pests of rice.

In Egypt, the stem borer, Chilo agamemnon Bles. is the most important insect attacking rice fields causing dead hearts in the vegetative stage and white heads in the reproductive stage. Annual rice yield losses due to this pest were estimated as 5-8 \% (El-Malky et al., 2013).

Most of the growers use scheduled insecticide applications to control insect pests, irrespective of insect attack, which results in many side effects including insect resistance to insecticides and environmental concerns (Suhail et al., 2008).

Reports about the level of white heads that significantly reduces rice yield are conflicting. Using the computer simulations, Rubia and Vries (1991) predicted that 20 $\%$ white heads, at the grain filling stage, can cause an almost proportionate yield reduction. Litsinger (2008) indicated that the level of $7 \%$ white head has no effect in reducing rice yield.

Due to lack of knowledge about the effect of white head symptom in reducing rice yield, the current investigation was undertaken to establish correlation between borer white head infestation and rice yield losses. This will contribute to determine the economic threshold and injury levels of $C$. agamemnon Bles infestation in rice fields.

\section{MATERIALS AND METHODS}

The current investigation was carried out at the Experimental Farm of Sakha Agricultural Research Station, Kafr EL-Sheikh Governorate during two successive seasons; 2013 and 2014. Two types of rice cultivars, Giza 178 (high tillering) and Egyptian Jasmine (medium tillering) were assigned to this study. The objective was to determine the economic threshold and economic injury levels of $C$. agamemnon Bles 
infestation in rice fields using simulated white head technique. In both seasons, clover was the preceding winter crop.

\section{Cultural Practices}

\subsection{Nursery preparation}

The rice nursery bed (one kerat $=175 \mathrm{~m}^{2}$ ) was prepared according to cultural practices recommendation. The land was tilled thrice, and calcium superphosphate $\left(15 \% \mathrm{P}_{2} \mathrm{O}_{5}\right)$ was incorporated into the soil before the last tillage at the rate of 150 $\mathrm{kg} /$ feddan. Before the dry leveling of the seed bed, nitrogenous fertilizer (Urea, $46.5 \%$ N) was incorporated into the soil at the rate of $69 \mathrm{~kg} /$ feddan. Then, the nursery was flooded, and wet leveled. Zinc sulphate was broadcasted as one kilogram/ Kerat just before seed broadcasting. Pregerminated seeds of Giza 178 and Egyptian Jasmine rice cultivars were broadcasted at the rate of $40 \mathrm{~kg} /$ feddan (two separated nurseries). The herbicide, thiobencarb (Saturn 50) at the rate of 2 liters/ feddan), mixed with sand, was broadcasted ten days after nursery flooding.

\subsection{Permanent field}

The permanent field was tilled thrice, with applying calcium superphosphate as done with the nursery. Nitrogen fertilizer was incorporated into the soil after last tillage at a rate of $23 \mathrm{~kg} /$ feddan, then, the field was flooded and wet leveled. One month after seed broadcasting, the rice seedlings were pulled out from the nursery, and moved to the permanent field. The seedlings were distributed, and transplanted at spacing of $20 \times 20 \mathrm{~cm}$, with 3- 4 seedlings per hill. The herbicide, thiobencarb (Saturn 50) at the rate of 2 liters/ feddan), mixed with sand, was broadcasted five days after permanent field flooding. Twenty and forty days after transplanting, the second and third doses (23 kg each) of nitrogen were applied as topdressing.

\section{Prevention of natural insect infestation}

To avoid the natural borer infestation, the permanent field was treated with carbofuran (Furadan $10 \mathrm{G}$ ) at rate of $6 \mathrm{~kg} /$ feddan twice, 20 and 40 days after transplanting.

\section{Experimental treatments}

The experiment was established in the first season (2013) as a pilot for determining a scale to be adopted for panicle removal to find out the economic threshold and injury levels of $C$. agmemnon infestation in rice. Therefore, two scales were used as follows:

\section{In 2013 season:}

The first scale was applied with Giza 178 cultivar as follows: 0, 4, 8, 12 \& 16\%. The second scale was applied with Egyptian Jasmine cultivar as follows; 0, 2, 4, 6, 8, 
$10,12,14 \& 16 \%$. The experimental area was divided into 15 plots ( 5 treatments $\times 3$ replicates) for Giza 178, and to 27 plots (9 treatments $\times 3$ replicates) for Egyptian Jasmine.

\section{In 2014 season:}

For both cultivars the used scale for panicle removal was $0,2,4,6,8,10,12$, $14 \& 16 \%$. The experimental area was divided into 27 plots ( 9 treatments $\times 3$ replicates) for each cultivar.

Treatments of both cultivars, in both seasons, were applied in an area of $2 \mathrm{~m}^{2}$ (50 hills) per panicle removal level. To determine the number of panicles required to be removed, the panicles in the 50 rice hills were counted, and the number of panicles needed to match the percentage of panicle removal was pulled out by hand ten days after complete heading.

\section{Yield and yield components}

\subsection{Panicle weight (g/panicle)}

Ten panicles, from each plot, were picked up and collectively weighed, and average weight of a panicle was calculated.

\subsection{0-grain weight (g)}

One thousand grains were taken from each plot, and average of 1000-grain weight was calculated

\subsection{Filled grain (\%)}

One hundred grains were taken from each plot, and examined for filled and unfilled grains, and percentage of filled grains was calculated.

\subsection{Grain yield $\left(\mathrm{g} / 50\right.$ hills $\left.=2 \mathrm{~m}^{2}\right)$}

From each plot, two square meters of guarded plants were harvested,

air-dried, threshed and winnowed. The grains were weighed to express the final yield of each plot.

\section{Statistical analysis:}

Data were subjected to analysis of variance, and the significantly different means were compared using Duncan's Multiple Range Test (1955).

\section{RESULTS AND DISCUSSION}

\section{2013 Season:}

Data of yield components of Giza 178 and Egyptian Jasmine cultivars are presented in Tables (1 and 2).

\subsection{Panicle weight (g/panicle):}

Variable levels of panicle removal had no significant effects on panicle weight in both cultivars. The weights ranged from 2.56 to $3.30 \mathrm{~g} /$ panicle in Giza 178 and from 4.12 to $4.96 \mathrm{~g} /$ panicle in Egyptian Jasmine. 


\subsection{0-grain weight (g):}

In Giza 178 cultivar (Table 1), the highest 1000-grain weight (20.78) was obtained from $16 \%$ panicle removal, followed by those at levels of 12 and $8 \%$, with values of 20.44 and $19.99 \mathrm{~g} / 1000$ grains, respectively. Similar results were obtained in Egyptian Jasmine, with $16 \%$ resulting in the heaviest panicles $(28.21 \mathrm{~g})$, followed by 14 and $12 \%$ with weights of 27.55 and $26.54 \mathrm{~g} / 1000$ grains, respectively. However, the lightest grain weights were obtained with the low levels (0,2 and $4 \%$ ) of panicle removal. Statistical analysis proved that variations in 1000-grain weight due to certain levels of panicle removal were significant.

Table 1. Effect of panicle removal (white head simulation) on yield components of Giza 178 rice cultivar, at the farm of Sakha Agricultural Research Station, 2013 season.

\begin{tabular}{|c|c|c|c|}
\hline $\begin{array}{c}\text { Panicle Removal } \\
(\%)\end{array}$ & $\begin{array}{c}\text { Panicle weight } \\
(\mathrm{g})\end{array}$ & $\begin{array}{c}\text { 1000-grain weight } \\
(\mathrm{g})\end{array}$ & $\begin{array}{c}\text { Filled grain } \\
(\%)\end{array}$ \\
\hline 0 & $3.30 \mathrm{a}$ & $19.39 \mathrm{~b}$ & $88.30 \mathrm{a}$ \\
\hline 4 & $2.78 \mathrm{a}$ & $19.28 \mathrm{~b}$ & $89.30 \mathrm{a}$ \\
\hline 8 & $2.82 \mathrm{a}$ & $19.99 \mathrm{ab}$ & $89.90 \mathrm{a}$ \\
\hline 12 & $2.58 \mathrm{a}$ & $20.44 \mathrm{ab}$ & $91.30 \mathrm{a}$ \\
\hline 16 & $2.56 \mathrm{a}$ & $20.78 \mathrm{a}$ & $92.60 \mathrm{a}$ \\
\hline
\end{tabular}

In a column, means followed by the same letter are not significantly different at the $5 \%$ level

Table 2. Effect of panicle removal (white head simulation) on yield and yield components of Egyptain Jasmine rice cultivar, at the farm of Sakha Agricultural Research Station, 2013 season.

\begin{tabular}{|c|c|c|c|}
\hline $\begin{array}{c}\text { Panicle Removal } \\
(\%)\end{array}$ & $\begin{array}{c}\text { Panicle weight } \\
(\mathrm{g})\end{array}$ & $\begin{array}{c}1000 \text {-grain } \\
\text { weight } \\
(\mathrm{g})\end{array}$ & $\begin{array}{c}\text { Filled } \\
\text { grain } \\
(\%)\end{array}$ \\
\hline 0 & $4.12 \mathrm{a}$ & $25.67 \mathrm{~cd}$ & $86.87 \mathrm{c}$ \\
\hline 2 & $4.13 \mathrm{a}$ & $25.20 \mathrm{~d}$ & $87.40 \mathrm{bc}$ \\
\hline 4 & $4.22 \mathrm{a}$ & $25.77 \mathrm{~cd}$ & $87.83 \mathrm{bc}$ \\
\hline 6 & $4.13 \mathrm{a}$ & $25.73 \mathrm{~cd}$ & $88.09 \mathrm{bc}$ \\
\hline 8 & $4.28 \mathrm{a}$ & $25.93 \mathrm{bcd}$ & $89.59 \mathrm{bc}$ \\
\hline 10 & $4.22 \mathrm{a}$ & $26.19 \mathrm{bcd}$ & $89.60 \mathrm{bc}$ \\
\hline 12 & $4.77 \mathrm{a}$ & $26.54 \mathrm{abc}$ & $90.35 \mathrm{~b}$ \\
\hline 14 & $4.93 \mathrm{a}$ & $27.55 \mathrm{a}$ & $90.84 \mathrm{~b}$ \\
\hline 16 & $4.96 \mathrm{a}$ & $28.21 \mathrm{ab}$ & $94.53 \mathrm{a}$ \\
\hline
\end{tabular}

In a column, means followed by the same letter are not significantly different at the $5 \%$ level

\subsection{Filled grain (\%):}

Statistical analysis revealed that the averages of filled grains $\%$ were not significantly different in Giza 178 cultivar, but significantly different in Egyptian 
Jasmine cultivar. In both cultivars, the highest percentage of filled grains was obtained with the highest levels of panicle removal, and vice versa.

\subsection{Grain yield $\left(\mathrm{g} / 2 \mathrm{~m}^{2}\right)$ :}

Estimation of grain yield was not available, as some rice plots were damaged by the invasion of rats.

\section{2014 Season:}

Data of yield and yield components of Giza 178 and Egyptian Jasmine cultivars are presented in Tables (3 and 4).

\subsection{Panicle weight (g/panicle):}

In Giza 178 cultivar, the heaviest panicle weights were recorded at 14 and 12 $\%$ removed panicles (3.86 and 3.81g/ panicle, respectively), while the lightest weights were obtained at 0,2 and $4 \%$ removal with values of $3.05,3.21$ and $3.18 \mathrm{~g} /$ panicle, respectively.

The same trend was found with Egyptian Jasmine cultivar, with 0, 2 and 4\% panicle removal giving the least weights; $3.15,3.62$ and $3.44 \mathrm{~g} /$ panicle, respectively. On the other hand, the highest values of panicle weights were obtained the highest levels of panicle removal; 5.66 and $5.72 \mathrm{~g} /$ panicle at 14 and $16 \%$ removal, respectively. The differences in both varieties were significant.

\subsubsection{0-grain weight (g):}

In both cultivars (Tables 3 and 4), the lowest values of 1000-grain weight were detected with the lowest percentages of panicle removal, while the greatest weights of 1000-grain were detected with the highest percentages of panicle removal.

In Giza 178 cultivar, 1000-grain weights were $20.71,20.65$ and $20.86 \mathrm{~g}$ at 0,2 and $4 \%$ panicle removal, respectively. At 14 and $16 \%$ removal, the 1000-grain weights increased to 22.81 and $22.76 \mathrm{~g}$, respectively.

The same trend was found with Egyptian Jasmine. The lowest 1000-grain weights; 24.60 , and $23.17 \mathrm{~g}$ were obtained at 0 and $2 \%$ panicle removal, respectively. On the other hand, the highest 1000-grain weights; 26.90 , and $26.93 \mathrm{~g}$ were obtained at 14 and $16 \%$ panicle removal, respectively. Statistical analysis revealed that the differences in both cultivars were significant.

\subsection{Filled grain (\%):}

In both cultivars, percentages of filled grains were higher with the higher levels of panicle removal, but lower with the lower levels. The differences in filled grains \% due to different levels of panicle removal were significant.

\subsection{Grain Yield $\left(\mathbf{g} / \mathbf{2} \mathbf{m}^{2}\right)$}

Panicle removal significantly reduced grain yield of both cultivars. 
In Giza 178, the highest grain yields were obtained at 0, 2 and $4 \%$ panicle removal, with values of 2315, 2295 and $2311 \mathrm{~g} / 2 \mathrm{~m}^{2}$, respectively without significant differences. The least grain yields were obtained at 12\% panicle removal (1951), 14\% (2075) and $16 \%\left(1833 \mathrm{~g} / 2 \mathrm{~m}^{2}\right)$. Similar results were obtained with Egyptian Jasmine. The yields were significantly the same at 0,2 and $4 \%$ panicle removal with values ranging between 1781 and $1815 \mathrm{~g} / 2 \mathrm{~m}^{2}$. The least values of grain yield were obtained at 14\% (1495 g/ $\left.2 \mathrm{~m}^{2}\right)$ and $16 \%$ panicle removal $\left(1265 \mathrm{~g} / 2 \mathrm{~m}^{2}\right)$.

Statistical analysis showed that yield differences, in both cultivars, were significant only in some treatments.

Table 3. Effect of panicle removal (white head simulation) on yield and yield components of Giza 178 rice cultivar, at the farm of Sakha Agricultural Research Station, 2014 season.

\begin{tabular}{|c|c|c|c|c|}
\hline $\begin{array}{c}\text { Panicle Removal } \\
(\%)\end{array}$ & $\begin{array}{c}\text { Panicle weight } \\
(\mathrm{g})\end{array}$ & $\begin{array}{c}\text { 1000-grain weight } \\
(\mathrm{g})\end{array}$ & $\begin{array}{c}\text { Filled grain } \\
(\%)\end{array}$ & $\begin{array}{c}\text { Yield } \\
\mathrm{g} / 2 \mathrm{~m}^{2} \\
(50 \mathrm{hill})\end{array}$ \\
\hline 0 & $3.05 \mathrm{~d}$ & $20.71 \mathrm{c}$ & $83.17 \mathrm{~d}$ & $2315 \mathrm{a}$ \\
\hline 2 & $3.21 \mathrm{c}$ & $20.65 \mathrm{c}$ & $83.60 \mathrm{c}$ & $2295 \mathrm{ab}$ \\
\hline 4 & $3.18 \mathrm{c}$ & $20.86 \mathrm{c}$ & $83.77 \mathrm{c}$ & $2311 \mathrm{a}$ \\
\hline 6 & $3.45 \mathrm{~b}$ & $21.49 \mathrm{c}$ & $84.51 \mathrm{bc}$ & $2273 \mathrm{~b}$ \\
\hline 8 & $3.59 \mathrm{ab}$ & $21.23 \mathrm{bc}$ & $88.12 \mathrm{~b}$ & $2230 \mathrm{bc}$ \\
\hline 10 & $3.68 \mathrm{a}$ & $21.88 \mathrm{~b}$ & $92.26 \mathrm{a}$ & $2232 \mathrm{bc}$ \\
\hline 12 & $3.81 \mathrm{a}$ & $22.55 \mathrm{a}$ & $93.11 \mathrm{a}$ & $1951 \mathrm{~cd}$ \\
\hline 14 & $3.86 \mathrm{a}$ & $22.81 \mathrm{a}$ & $92.08 \mathrm{a}$ & $2075 \mathrm{c}$ \\
\hline 16 & $3.77 \mathrm{a}$ & $22.76 \mathrm{a}$ & $93.12 \mathrm{a}$ & $1833 \mathrm{~d}$ \\
\hline
\end{tabular}

In a column, means followed by the same letter are not significantly different at the $5 \%$ level

Table 4. Effect of panicle removal (white head simulation) on yield and yield components of Egyptain Jasmine rice cultivar, at the farm of Sakha Agricultural Research Station, 2014 season.

\begin{tabular}{|c|c|c|c|c|}
\hline $\begin{array}{c}\text { Panicle Removal } \\
(\%)\end{array}$ & $\begin{array}{c}\text { Panicle weight } \\
(\mathrm{g})\end{array}$ & $\begin{array}{c}1000 \text {-grain weight } \\
(\mathrm{g})\end{array}$ & $\begin{array}{c}\text { Filled grain } \\
(\%)\end{array}$ & $\begin{array}{c}\text { Yield } \\
\mathrm{g} / 2 \mathrm{~m}^{2}(50 \mathrm{hills})\end{array}$ \\
\hline 0 & $3.15 \mathrm{e}$ & $24.60 \mathrm{~d}$ & $84.16 \mathrm{e}$ & $1815 \mathrm{a}$ \\
\hline 2 & $3.62 \mathrm{~d}$ & $23.17 \mathrm{~cd}$ & $86.77 \mathrm{be}$ & $1755 \mathrm{a}$ \\
\hline 4 & $3.44 \mathrm{~d}$ & $24.81 \mathrm{~d}$ & $88.91 \mathrm{~cd}$ & $1781 \mathrm{a}$ \\
\hline 6 & $4.02 \mathrm{~cd}$ & $25.56 \mathrm{c}$ & $87.42 \mathrm{c}$ & $1750 \mathrm{a}$ \\
\hline 8 & $4.00 \mathrm{c}$ & $25.76 \mathrm{c}$ & $89.65 \mathrm{~b}$ & $1747 \mathrm{a}$ \\
\hline 10 & $4.28 \mathrm{bc}$ & $26.14 \mathrm{~b}$ & $89.92 \mathrm{~b}$ & $1597 \mathrm{~b}$ \\
\hline 12 & $4.91 \mathrm{~b}$ & $26.38 \mathrm{ab}$ & $90.17 \mathrm{ab}$ & $1623 \mathrm{~b}$ \\
\hline 14 & $5.66 \mathrm{a}$ & $26.90 \mathrm{a}$ & $92.36 \mathrm{a}$ & $1495 \mathrm{c}$ \\
\hline 16 & $5.72 \mathrm{a}$ & $26.93 \mathrm{a}$ & $94.59 \mathrm{a}$ & $1265 \mathrm{~d}$ \\
\hline
\end{tabular}

In a column, means followed by the same letter are not significantly different at the $5 \%$ level 


\section{Economic threshold and economic injury levels (ETL \& EIL):}

\subsection{Giza 178}

Data presented in Table (5) show the effect of panicle removal on rice yield of Giza 178 cultivar. The check (no panicle removal) yielded 4.630 Ton / fed which was reduced to 4.590 and $4.622 \mathrm{t} /$ fed at 2 and $4 \%$ panicle removal, respectively. The lowest grain yields were obtained at 12,14 and $16 \%$ panicle removal. In terms of yield losses, $10 \%$ panicle removal induced $166 \mathrm{~kg}$ reduction/fed which is less the cost of chemical control (350 L.E/fed). The following level of panicle removal (12\%) resulted in a loss of $728 \mathrm{~kg} / \mathrm{fed}$, i.e. $1456 \mathrm{~L}$. E. The latter monetary value is higher than the cost of chemical control. Accordingly, the economic threshold level could be considered as $10 \%$ panicle removal (stimulated white head), while the economic injury level could be considered as $12 \%$ panicle removal, as the loss in yield and monetary are higher than the cost of chemical control.

\subsection{Egyptian Jasmine:}

Data presented in Table (6) show the effect of different levels of panicle removal on reductions in rice yield, and monetary. The rice yields were reduced by $120,68,130$ and $136 \mathrm{~kg} / \mathrm{fed}$ at 2, 4, 6 and $8 \%$ panicle removal. Up to $8 \%$ panicle removal, the monetary reduction was calculated as $340 \mathrm{~L}$. E. per feddan, which is less than the cost of chemical control ( $350 \mathrm{~L}$. E. /fed). Thus, this level could be considered as the economic threshold level for the infestation of rice stem borer (stimulated white head). Beyond $8 \%$, the yield loss accounted for $436 \mathrm{~kg} / \mathrm{fed}$, that equals 1090 L.E., which is higher than the cost of chemical control. Consequently, the level of $10 \%$ panicle removal (stimulated white head) is considered the economic injury level. 
Table 5. Economic analysis of Giza 178 rice cultivar for evaluating the economic threshold and injury level (ETL \& EIL)

\begin{tabular}{|c|c|c|c|c|c|}
\hline $\begin{array}{c}\text { Panicle } \\
\text { removal \% }\end{array}$ & $\begin{array}{c}\text { Yield / } \\
2 \mathrm{~m}^{2} \\
\mathrm{~g}\end{array}$ & $\begin{array}{c}\text { Yield/fed } \\
\text { Ton }\end{array}$ & $\begin{array}{c}\text { Yield } \\
\text { reduction/Fed } \\
\mathrm{Kg}\end{array}$ & $\begin{array}{c}\text { Monetary } \\
\text { reduction/fed } \\
\text { L.E. }\end{array}$ & $\begin{array}{c}\text { Control cost } \\
\text { L.E. }\end{array}$ \\
\hline 0 & $2315 \mathrm{a}$ & 4.630 & - & - & 350 \\
\hline 2 & $2295 \mathrm{ab}$ & 4.590 & 40 & 80 & 350 \\
\hline 4 & $2311 \mathrm{a}$ & 4.622 & 8 & 16 & 350 \\
\hline 6 & $2273 \mathrm{~b}$ & 4.546 & 84 & 168 & 350 \\
\hline 8 & $2230 \mathrm{bc}$ & 4.460 & 170 & 340 & 350 \\
\hline 10 & $2232 \mathrm{bc}$ & 4.464 & 166 & 332 & 350 \\
\hline 12 & $1951 \mathrm{~cd}$ & 3.902 & 728 & 1456 & 350 \\
\hline 14 & $2075 \mathrm{c}$ & 4.150 & 480 & 960 & 350 \\
\hline 16 & $1833 \mathrm{~d}$ & 3.666 & 964 & 1938 & 350 \\
\hline
\end{tabular}

- In a column, means followed by the same letter are not significantly different at the $5 \%$ level

- Insecticide value: $8 \mathrm{Kg}$ carbofuran (Furadan $10 \mathrm{G}$ ), as two treatments, x 40 L.E. $/ \mathrm{kg}=320$ L.E.

- $\quad$ Labor cost $=30 \mathrm{~L}$. E. (one labor to broadcast Furadan)

- Total control cost $=320+30=350 \mathrm{~L}$. E.

- $\quad$ One ton of paddy rice $=2000 \mathrm{~L}$. $\mathrm{E}$.

Table 6. Economic analysis of Egyptian Jasmine rice cultivar for evaluating the economic threshold and injury levels (ETL \& EIL).

\begin{tabular}{|c|c|c|c|c|c|}
\hline $\begin{array}{c}\text { Panicle } \\
\text { removal \% }\end{array}$ & $\begin{array}{c}\text { Yield } \\
/ 2 \mathrm{~m}^{2} \\
\mathrm{~g}\end{array}$ & $\begin{array}{c}\text { Yield/fed } \\
\text { Ton }\end{array}$ & $\begin{array}{c}\text { Yield } \\
\text { reduction/fed } \\
\mathrm{Kg}\end{array}$ & $\begin{array}{c}\text { Monetary } \\
\text { reduction/fed } \\
\text { L.E. }\end{array}$ & $\begin{array}{c}\text { Control cost } \\
\text { L.E. }\end{array}$ \\
\hline 0 & $1815 \mathrm{a}$ & 3.630 & - & - & 350 \\
\hline 2 & $1755 \mathrm{a}$ & 3.510 & 120 & 300 & 350 \\
\hline 4 & $1781 \mathrm{a}$ & 3.562 & 68 & 170 & 350 \\
\hline 6 & $1750 \mathrm{a}$ & 3.500 & 130 & 325 & 350 \\
\hline 8 & $1747 \mathrm{a}$ & 3.494 & 136 & 340 & 350 \\
\hline 10 & $1597 \mathrm{~b}$ & 3.194 & 436 & 1090 & 350 \\
\hline 12 & $1623 \mathrm{~b}$ & 3.246 & 384 & 960 & 350 \\
\hline 14 & $1495 \mathrm{c}$ & 2.990 & 640 & 1600 & 350 \\
\hline 16 & $1265 \mathrm{~d}$ & 2.530 & 1100 & 2750 & 350 \\
\hline
\end{tabular}

- In a column, means followed by the same letter are not significantly different at the $5 \%$ level

- Insecticide value: $8 \mathrm{Kg}$ carbofuran (Furadan 10G), as two treatments, x 40 L.E. $/ \mathrm{kg}=320$ L.E.

- $\quad$ Labor cost $=30 \mathrm{~L}$. E. (one labor to broadcast Furadan)

- Total control cost $=320+30=350 \mathrm{~L}$. E.

- One ton of paddy rice $=2500 \mathrm{~L}$. $\mathrm{E}$. 
Rice stem borer, Chilo agamemnon Bles. infestation results in two main symptoms of damage, dead hearts during vegetative stage, and white heads during reproductive stage. In many cases, rice plants are capable of compensating for dead hearts, particularly if infestation occurs before maximum tillering stage (Sherif et al. 1999). The relationship between damage by stem borers and yield loss is complex because stem borer effects on rice yield vary with pest population intensity, time of damage and growing conditions (Feijen 1979). Rice plants may compensate for damage during early growth stages (Ahmed 1984). In the current study, panicle weight, 1000-grain weight and percentage of filled grains exhibited high values when more panicles were removed. This could be interpreted in the light of phenomenon of compensation (Rubia et al, 1996), i.e. the nutrients that should be going to removed panicles, will translocate to the remaining panicles. Thus, the latter panicles become healthier than normal. This means that the yield loss is not linearly correlated with the percentage of removed panicles. In such concern, Rubia et al. (1987) suggested that the extent to which rice plants are able to overcome the stem borer damage is needed to be investigated. The decision makers as well as the growers are seriously wiling to correlate insect infestation with the yield loss to adopt control measures at the appreciate time

Rubia et al. (1987) found a significant relationship between high density of white heads by natural stem borer infestation and rice yield, however, no significant yield losses occurred up to $10 \%$ white heads. Way (2003) recommended development and implementation of economic threshold as a rational approach to pest control management designed to aid farmers in making pest control decisions. Sherwat et al. (2007) assessed the economic threshold level of rice stem borer infestation in rice as $7.5 \%$ infestation. However, the economic threshold level was determined by Suhail et al. (2008) at a lower level, i.e. $5 \%$ infestation. Reji et al. (2008) reported that the variations in economic threshold levels are due to locations and circumstances dominant at conducting the assessment. Researches of Litsinger (2008) indicated that stem borer economic threshold level is only $2-4 \%$ white heads for high value rice varieties.

For Giza 178, the economic threshold was determined at $10 \%$ panicle removal (= $10 \%$ white head), while the economic injury level was determined at $12 \%$ panicle removal. For Egyptian Jasmine, the economic threshold and economic injury levels were determined as 8 and $10 \%$, panicle removal, respectively. 


\section{REFERENCES}

1. Ahmed, M. 1984. A sample study of stem borer infestation of rice crop and its expected effects on yield of rice at Gujjo (Sind). Pakistan J. Sci and Indust. Res. 27: $33-37$.

2. Anonymous. 2000. Agricultural Statistics of Pakistan Govt. Pak. Food and Agric. Div., Econ. Wing, Islamabad, pp: $45-46$.

3. Duncan, D. B. 1955. Multiple range and multiple test. Biometrics, 11: 1- 42.

4. El-Malky, M. M.; M. M. El-Habashy, S. A. A. Hzmmoud and M. R. Sherif. 2013. Genetic studies on some rice varieties for rice stem borer, Chilo agamemnon Bles., and agronomic characters under Egyptian condition. Egypt. J. Plant Breed. 17(2): $196-212$.

5. Feijen, H. R. 1979. Economic importance of rice stem borer (Diopsis macropthalma) in Malawi. Experimental Agriculture, 15: 177-186.

6. Litsinger J.A. 2008. Yield loss and the green revolution? In: Peshin R., A.K. Dhawan, eds. Integrated Pest Management: Innovation-Development Process, Berlin: Springer Science + Media BV. (1): 387-495

7. Pathak, M.D.; M.D. Jeshwani; and R.N. Singh. 2002. Farmers participatory IPM in Basmati rice -a case study. Annuals of Plant Protection Science, 10:386-388.

8. Reji, G., S. Chander and P. K. Aggarwal. 2008. Simulating rice stem borer،Scirpophaga incertulas damage for developing decision support tools. Crop Prot., 27:1194-1199.

9. Rubia, E. G. and , F. W. T. Vries. 1991. Simulation of rice yield reduction caused by stem borer (SB), International Rice Research Newseletter, 11: 1-34.

10. Rubia, E. G.; B. M. Shepard; E. B. Yzmbza; K. T. Ingram; G. S. Arida and F. Penning de Vries. 1987. Stem borer damage and grain yield of flooded rice. Journal of Plant Protection in the Tropics, 6(3): $205-211$.

11. Rubia, E. G.; K. L. Heong; M. Zalucki; B. Gonzales and G. A. Norton. 1996. Mechanism of compensation of rice plants to yellow stem borer Sciropophaga incertules (Walker) injury. Crop Prot., 15: 335.

12. Sherawat, S. M.; M. Inayat; T. Ahmad and M. K. Maqsood. 2007. Determination of economic threshold levels (ETL) for chemical control of rice stems borers. J. Agric. Res., 45(1): 55 - 59.

13. Sherif, M. R.; F. E. Abdalla and A. M. Soliman. 1999. Major insects of rice plants in Egypt and their management. Adv. Agric. Res. Egypt. 2(3): 188-219.

14. Suhail, A.; J. Ahmad; M. Asghar; M. Tzyyib and M. Mzjeed. 2008. Determination of economic threshold level for the chemical control of rice stems borers (Sciropophaga incertules WIk. and Sciropophaga innotata WIk.). Pak. Entomol., 30(2): $175-178$.

15. Way, M. O. 2003. Rice arthropod pests and their management in the United States, pp. 437-456. In C. W. Smith and R. H. Dilday (eds.), Rice: Origin, History, Technology, and Production. John Wiley \& Sons, Inc. Hoboken, NJ. 


\section{الحد الحرج ، وحد الضرر الاقتصادى للإصابة بثاقبة ساق الأرز ،

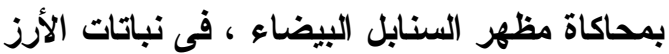

\section{أمانى سامى الحفنى}

قسم بحوث آفات الدحاصيل الحقلية ، معهة بحوث وقاية النباتات ، مركز الحوث الزراعية ، الدقى ، الجيزة.

يحتل الأرز المرتبة الثانية بعد القمح ، من حيث المساحة و الإنتاج على مستوى العالم.

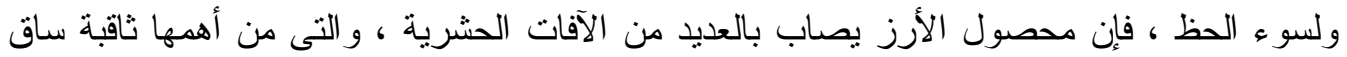
الأرز . Chilo agamemnon Bles. أجريت الدراسة الحالية بمحطة بحوث سخا محافظة كفر الثيخ

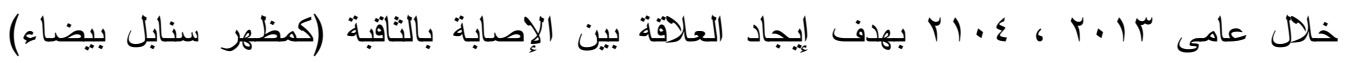
وخسائر المحصول ، ومن ثم تقدير الحد الحرج ، وحد الضرر الاقتصادى لإصابة الأرز بالثاقبة.

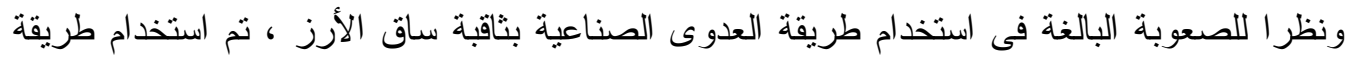

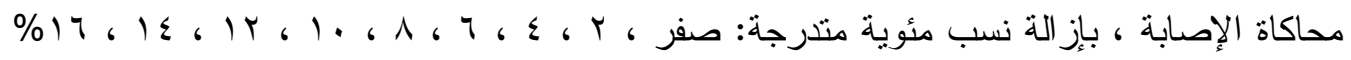

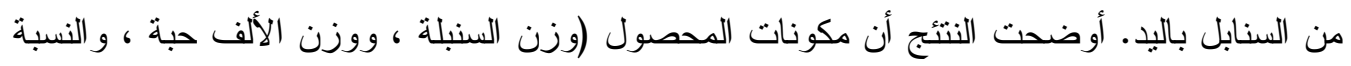

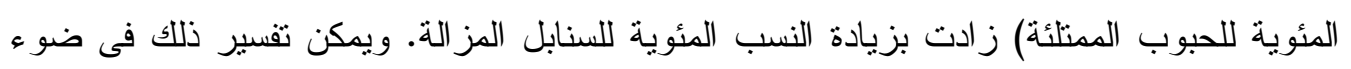
نظرية التعويض ، حيث ينتقل الغذاء الذى كان مخصصا للسنابل المزالة ، إلى السنابل المجاورة

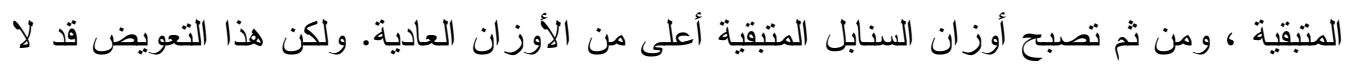

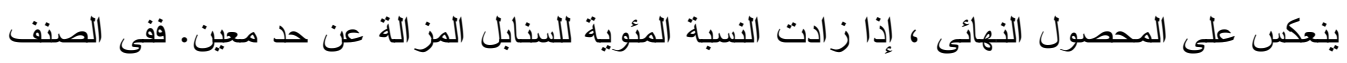

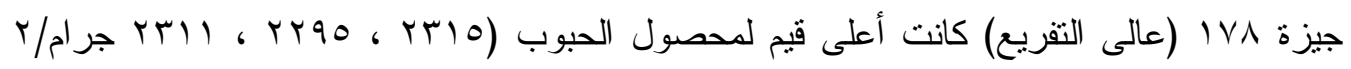

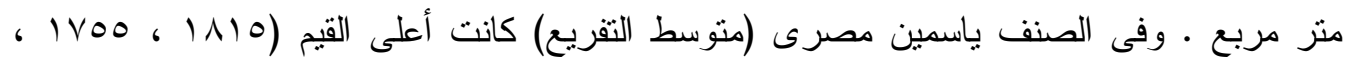

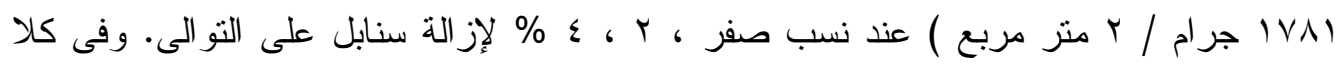

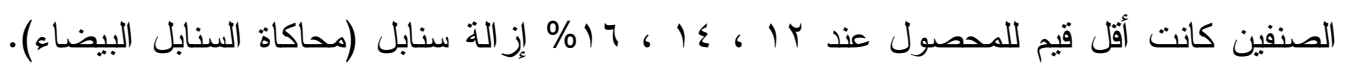

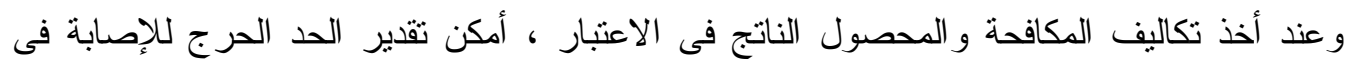

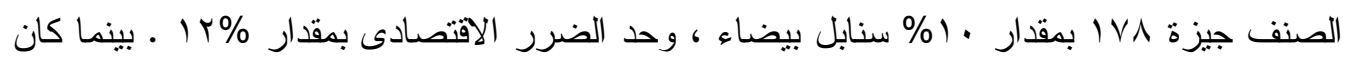

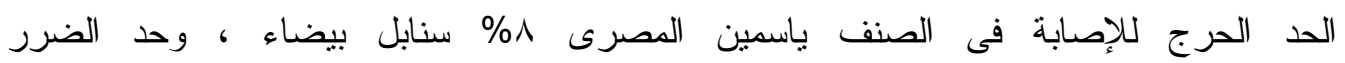
الاقتصادى•(1\%. ومن الملاحظ ، فى ضوء هذه التجربة ، زيادة قيمة الحد الحرج وحد الضرر

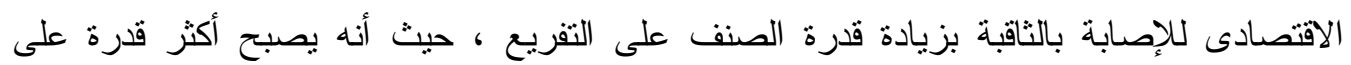

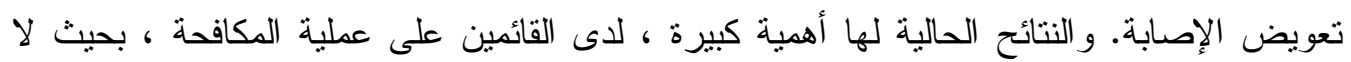

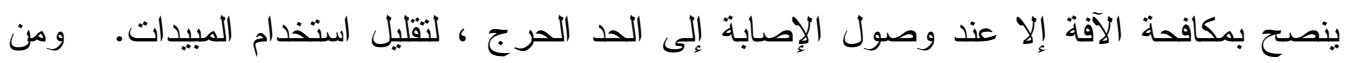

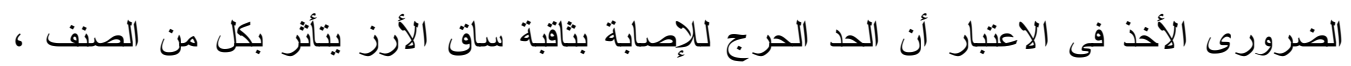
و المنطقة ، والعمليات الزر اعية المتبعة ، وأسعار المبيدات الحشرية ، وأسعار الأرز السائدة. 